\title{
Study of Economic Literacy Level Among Primary School Students
}

\author{
Riska Pristiani, Elementary Education Department, Universitas Negeri Malang, \\ riska.pristiani.pasca@um.ac.id, ORCHID ID https://orcid.org/0000-0002-7454-1331 \\ Hari Wahyono, Economics Education Department, Universitas Negeri Malang, hari.wahyono.fe@um.ac.id, \\ ORCHID ID https://orcid.org/0000-0003-4497-5961 \\ Mit Witjaksono, Economics Education Department, Universitas Negeri Malang, \\ mit.witjaksono.fe@um.ac.id, ORCHID ID https://orcid.org/0000-0002-3065-7180 \\ JG Nirbito, Economic Education Department, Universitas Negeri Malang, nirbitojg@gmail.com, ORCHID ID \\ https://orchid.org/0000-0002-4540-8267
}

\begin{abstract}
As economic literacy among children mostly measured by the level of their knowledge, this paper aimed to describe the economic literacy level of primary school student with deeper explanation. Economic literacy analysed with descriptive technique through three different aspect including knowledge, attitude and skill. As the result of this study, the level of economic literacy among primary school students is still low. The lack of economic literacy among primary school children pictured in every aspect such as their knowledge, attitude, and skill. Deeper concern should be given to this condition as economic literacy also have important rule since early age of our children.
\end{abstract}

Keywords: Economic Literacy, Primary School, Children, Evaluation

$\begin{array}{lll}\text { Received: } 10.11 .2020 & \text { Accepted: 23.12.2020 } & \text { Published: } 14.01 .2021\end{array}$

\section{INTRODUCTION}

Literacy is basically an ability and skill that includes listening, speaking, reading, and writing (Rini, 2018). Over time, the notion of literacy has also developed into multiliteration, namely the ability to communicate over differences in information, language, culture, education, economy, and technology through various processes (Thibaut \& Curwood, 2018). Burkhardt et al. (2003) clarified that multiliteration can be perceived into various perspective, for example, Basic Literacy, Scientific Literacy, Economic Literacy, Technological Literacy, Visual Literacy, Information Literacy, Multicultural Literacy, and Global Awareness. Studying a multiliterative point of view means learning the various abilities needed in life and one of the multiliteration viewpoints that play a direct role in life skills is Economic Literacy.

Economic education is very important to be taught at school as student nowadays need it to help them think, act, and do everything related to their economic daily life activities. By learning economy, they can understand how global economy works and then decide the best choice for their economic decision that should be taken. Since each person should be a maker and a shopper and furthermore to follow the financial strategy of the nation regardless of what financial or socio social climate s/he is in. Monetary proficiency, hence, is vital to the youngsters of the 21st century (Akhan, 2015). By expanding their monetary proficiency level, individuals separately empowers themself to act objectively in their monetary dynamic. At the point when somebody acts objectively, they can evade over the top getting, utilize monetary instruments all the more proficiently, make money saving advantage examination in his/her choices and comprehend and characterize financial ideas (Ünal et al., 2015). Financial proficiency is of high significance for explicit social gatherings as well as all the people. Expansion in financial proficiency of the people influences the people as well as adds to the general public and nation. (Yayar \& Karaca, 2017).

Previous research indicated that economic literacy not being an important knowledge as other literacies. Even after most states started to command financial matters educational plans for each evaluation level start with kindergarten, shockingly little consideration has been paid to the reasonableness of these ordered ideas in the essential evaluations of primary school (Hawthorne et al., 2003). Most of school understudies in Germany move on from general auxiliary schools, where monetary substance isn't instructed methodicallly, yet rather, generally, remembered for different subjects, for example, social examinations. Financial aspects is offered as a different subject at general optional schools in a couple of government states in Germany. One open door for understudies to learn financial substance before beginning a degree program is to go to a business upper auxiliary school, where business and financial aspects are instructed as isolated major or minor subjects (Happ et al., 2016). (Henning \& Lucey, 
2017) affirmed that lone $13 \%$ of instructor teachers and $25 \%$ of pre-administration educators believed that it was imperative to show monetary proficiency in rudimentary schooling. Rudimentary preadministration instructors and instructor teachers esteem social investigations schooling (and monetary proficiency) not as much as perusing and science training.

In fact, the proof shows that school-based monetary instruction projects can improve youngsters' and teenagers' monetary information and mentalities. Studies that survey the goal to rehearse great conduct and studies dependent on self-detailed conduct likewise report constructive outcomes (Amagir et al., 2018). Money related instruction levels in India were found to be lower than those in made countries. Understudies who looked for after the business/ financial things stream of instruction were found to have more lifted levels of finan-cial capability than understudies looking for after the science stream.

Results demonstrated that understudies, regardless of having significant levels of numeracy, couldn't move that information to do monetary calculations (Jayaraman \& Jambunathan, 2018). Economic literacy is very important to be applied by students through learning in school and daily life. Economic literacy learning aims to provide opportunities for students to understand deeply and apply knowledge from economic concepts that have been learned in the classroom (Salemi, 2005). In simple terms, students can decide about what they will do now and in the future by studying various aspects of prevailing economic policy. Several studies have shown that several schools, especially primary schools in developed countries, have implemented the discipline of economic literacy in their learning (W. B. Bosshardt \& Walstad, 2019); (Henning \& Lucey, 2017); (Whitlock, 2018). The research shows that the primary school students studied define and apply simple economics. With the new school educational program ordering less instead of more financial aspects and individual budget coursework, alumni of the educational system will probably be less ready for the difficulties of the monetary and monetary world into which they arise. Endeavors to teach everyone outside the school climate ought to improve the circumstance to some degree; in any case, assaulting monetary and monetary ignorance through youth training in a school setting may significantly reinforce progress toward a monetarily proficient society (Amidjono et al., 2016).

Economic literacy for children has been measured through few previous researches. Sari and Fatimah (Sari et al., 2017) estimated information part of understudy monetary education through appraisal dependent on Financial Intelligence Curriculum for primary school understudies from grade 16 , zeroing in on the need and need, need needs, pay, spending, saving, and sharing. Another knowledge measurement of economic literacy according to the Financial Literacy Standards was conducted by (Opletalová, 2015) , and other knowledge measurement of economic literacy by (Ciemleja, 2016). In behavior aspect, economic literacy was measured through experimental method (Sutter et al., 2019).

Based on these results, there is no attitude aspect of economic literacy of children age was measured. A comprehensive measurement of economic literacy for children needed to be arranged including knowledge, attitude and skill aspect. This issue is partially addressed in this study.

\section{METHOD}

This research is an evaluation research with a quantitative approach. A quantitative approach is used to measure economic literacy level of primary school students which is described into knowledge, attitudes, and skills aspects. Population of this research are $9^{\text {th }}$ grade students of Public Primary School of Malang City. Sampling in this study using purposive random sampling technique. The selected area is four State Junior High Schools in Klojen District with the consideration to can represent the best school condition of economic learning quality at the basic education level in Malang City.. In each school, two classes were taken as the research sample. Totally, they are 254 student participated as research samples.

The research variable is the level of economic literacy of primary school students. The literacy level is described in three sub variables, namely knowledge, attitudes, and skills. Measuring the level of economic literacy uses the main reference based on the National Council of Economic Education standards which is modified by input recommendations from competent teachers (W. Bosshardt \& Walstad, 2014). The measurement of the knowledge aspect uses a test consisting of 50 multiple choice questions. The indicators measured include the basic concepts of economics, microeconomic concepts, macroeconomic concepts, international economic concepts, economic development concepts, and the Indonesian economic system. To Measure students' attitudes in economic behaviour, we use measurement instruments that include attitudes related to consumptive activities, making wise decisions, applying the values contained in the Indonesian economic system, creative economy (home economics and household economics), and entrepreneurial activities. This instrument was developed into 15 questions with scoring scale of 1 to 3 . The measurement of student skills in economic 
behavior using instrument that developed in order of based skills to manage personal money and behavioral skills of production. The instrument for measuring skills was developed into 10 questions with a scoring scale of 0 to 1 . All data collected through tests and instrument entries were analyzed descriptively with percentage techniques.

\section{RESULT}

Based on the test results collected from student answers, the findings regarding the level of economic literacy of primary school students can be described as follows:

\section{Knowledge Aspect}

Distribution results of knowledge test related to literacy economics are presented in Table 1 below:

Table 1. Distribution of Economic Literacy Test Results on Knowledge Aspect

\begin{tabular}{|l|l|c|l|l|}
\hline No & Interval class & Frequency & \% & Criteria \\
\hline 1 & $1-20$ & 0 & 0 & Very less \\
\hline 2 & $21-40$ & 10 & 3,94 & Less \\
\hline 3 & $41-60$ & 143 & 56,30 & Pretty good \\
\hline 4 & $61-80$ & 99 & 38,98 & Well \\
\hline 5 & $81-100$ & 2 & 0,78 & Very good \\
\hline \multicolumn{2}{|l|}{ TOTAL } & 254 & 100,00 & \\
\hline
\end{tabular}

Source: compiled from research results.

Based on the data in Table 1, it can be seen that most students didn't have a good levels of economic literacy in knowledge aspect with the percentage of 56,30\%. It needs to be understood if most of them have a mastery that is not pretty good, because the gap between the problems created with measurements that have been carried out in schools during learning activities. An interpretation can be made that learning economics is currently not able to provide understanding and mastery of economics that should be for students. This is because the economic learning absorbed by students does not cover all the main material that is used as the basis for preparing the test instrument. The gap between the learning experiences that students have with the subject matter of tests of students' knowledge of problems and economics, can be ascertained to be one of the causes of the low achievement of students on the given tests. It can be concluded that the implementation of economic learning at the basic education level is not effective because it has not been able to provide an understanding and mastery of the problems and economics that should be.

\section{Attitude Aspect}

Distribution results of attitude test related to literacy economics are presented in Table 2 below:

Table 2. Distribution of Economic Literacy Test Results on Attitude Aspect

\begin{tabular}{|c|c|c|c|}
\hline No & Component & Frequency & $\%$ \\
\hline 1 & $\begin{array}{l}\text { Use the money to buy credit and the remaining money if } \\
\text { sufficient can be used to buy food }\end{array}$ & 121 & $47,64 \%$ \\
\hline 2 & $\begin{array}{l}\text { Supermarkets (supermarkets), considering that they are more } \\
\text { complete and convenient than shopping at the market, although } \\
\text { they are more expensive, the quality of the goods is guaranteed } \\
\text { and more prestigious. }\end{array}$ & 158 & $62,20 \%$ \\
\hline 3 & $\begin{array}{l}\text { Any food as long as the price is cheap and the portions are large, } \\
\text { such as nasi padang, cilok, ice puter, instant noodles, cireng, etc. }\end{array}$ & 151 & $59,45 \%$ \\
\hline 4 & $\begin{array}{l}\text { Think hard how you can buy these two items, both bags and } \\
\text { shoes because there is a thought that "discount is a limited } \\
\text { moment" }\end{array}$ & 139 & $54,72 \%$ \\
\hline 5 & $\begin{array}{l}\text { Information about discounts on goods or services that will be } \\
\text { purchased before shopping }\end{array}$ & 151 & $59,45 \%$ \\
\hline 6 & Buy expensive things and invest them to save and sell one day. & 150 & $59,06 \%$ \\
\hline 7 & $\begin{array}{l}\text { Enthusiastic when entering a shop to find information about the } \\
\text { type, quality, and price of the item because you think that if you } \\
\text { have enough money then one day you will buy it. }\end{array}$ & 160 & $62,99 \%$ \\
\hline 8 & You doubt that rich and poor are someone's destiny or lifeline & 143 & $56,30 \%$ \\
\hline
\end{tabular}




\begin{tabular}{|l|l|l|l|}
\hline & that cannot be changed. & & \\
\hline 9 & $\begin{array}{l}\text { Borrow some money from your friends so you can still snack at } \\
\text { school. }\end{array}$ & 131 & $51,57 \%$ \\
\hline 10 & $\begin{array}{l}\text { Participate in learning activities with enthusiasm and } \\
\text { responsibility }\end{array}$ & 112 & $44,09 \%$ \\
\hline 11 & $\begin{array}{l}\text { You pay the bill (moral value required here, honesty level in the } \\
\text { honesty canteen) }\end{array}$ & 157 & $61,81 \%$ \\
\hline 12 & $\begin{array}{l}\text { Buy goods and services at online stores Shopee, Bukalapak, } \\
\text { Lazada, etc.). Policy in consuming e-commerce is needed here. }\end{array}$ & 113 & $44,49 \%$ \\
\hline 13 & You look at my peers to compare answers & 129 & $50,79 \%$ \\
\hline 14 & You take a course or tutoring half-heartedly. & 119 & $46,85 \%$ \\
\hline 15 & Directly buy goods because there is a discount & 167 & $65,75 \%$ \\
\hline & Average & 140 & $55,12 \%$ \\
\hline
\end{tabular}

Source: compiled from research results.

Based on Table 2, it can be seen that students tend to be less wise in relation to economic literacy with an attitude score percentage of $55,12 \%$. This can be seen from their attitude in consuming an item or food, being tempted by a discount, lack of understanding of the form of self-investment for the future, seen from their cheating attitude, lack of enthusiasm in taking additional lessons, and a lack of inculcating a positive thinking mind set. Based on the results of follow-up interviews, it is indicated that this is because learning activities (curriculum, teachers and textbooks) do not install the proper attitude in economic behaviour. From the assessment indicators developed, it can be concluded that students tend to be weak in determining attitudes related to rationality and consumptive activities.

\section{Skills Aspect}

Distribution results of skills test related to literacy economics are presented in Table 3 below:

Table 3. Distribution of Economic Literacy Test Results on Skills Aspect

\begin{tabular}{|l|l|l|l|}
\hline No & Component & Frequency & \% \\
\hline 1 & $\begin{array}{l}\text { Have ever felt disappointed after buying an item (the } \\
\text { price and quality of the item are not comparable, the } \\
\text { benefits of the item do not exist) }\end{array}$ & 208 & $81.89 \%$ \\
\hline 2 & $\begin{array}{l}\text { Have returned items that you accidentally found } \\
\text { somewhere. (morality and the level of honesty in } \\
\text { obtaining income are needed to be instilled in children } \\
\text { early on) }\end{array}$ & 232 & $91.34 \%$ \\
\hline 3 & $\begin{array}{l}\text { Never save part of the allowance your parents gave you } \\
\text { to save }\end{array}$ & 159 & $62.60 \%$ \\
\hline 4 & Never buy things in instalments & 174 & $68.50 \%$ \\
\hline 5 & $\begin{array}{l}\text { Never record every money you receive and spend during } \\
\text { the day }\end{array}$ & 178 & $70.08 \%$ \\
\hline 6 & $\begin{array}{l}\text { Once sold an item to your classmate. (the ability to be } \\
\text { entrepreneurial from childhood needs to be instilled in } \\
\text { children from an early age) }\end{array}$ & 132 & $51.97 \%$ \\
\hline 7 & $\begin{array}{l}\text { Ever been so excited when he took lessons in dance, fine } \\
\text { arts, and music. }\end{array}$ & 174 & $68.50 \%$ \\
\hline 8 & $\begin{array}{l}\text { Have bought goods or services because you wanted } \\
\text { them, not because you needed them.. }\end{array}$ & 193 & $75.98 \%$ \\
\hline 9 & Never bought an item that says "buy 2 get 1 free" & 182 & $71.65 \%$ \\
\hline 10 & $\begin{array}{l}\text { Never before going to shop, first register the goods or } \\
\text { services that will be purchased later }\end{array}$ & 189 & $74.41 \%$ \\
\hline & Average & 180 & $71.65 \%$ \\
\hline
\end{tabular}

Source: compiled from research results.

From Table 3, it can be concluded that the level of economic literacy of students in the skill aspect is also not optimal. This is reflected in the average skill score of $71,65 \%$. Slightly contradicting the aspects of knowledge and attitudes, it turns out that students' economic literacy in the skills aspect is actually better. Based on Table 3 , it can be seen that the value of honesty is still firmly held by elementary education students, seen from their skills in returning items that you accidentally found 
somewhere. Judging from the assessment indicators developed, students tend to be weak in skills related to entrepreneurship, making decisions when there are discount/promo rights, distinguishing between needs and wants, and the ability to manage finances.

\section{DISCUSSION}

Based on the result of this research, we can say that the lack of economic literacy among student based on this finding related with previous research by Lusardi and (Lusardi \& de Bassa Scheresberg, 2015) that conclused monetary proficiency among the youngsters in USA is low and less than one-third of youthful grown-ups have fundamental information on loan fees, swelling and danger enhancement. Other investigation by (Garg \& Singh, 2018), reveals that the financial capability level among youth is moo over the foremost piece of the world that has ended up a reason for concern.

This finding additionally upheld by the aftereffect of past examination that found The absence of understudies' comprehension of essential monetary ideas, for example, the trouble of understudies dealing with their funds (Nurjanah et al., 2018) and other investigation that said youngsters have restricted information about financial issues with high changeability in what concerns their comprehension of financial issues (Varum and Ferreira, 2014).

The lack of economic literacy in attitude aspect as explained in Table 2 influenced by the lack of student knowledge as written in Table 1 . This situation related with by previous research that said the economic literacy of the business owners related with attitudes (KOMȘU et al., 2018). The relation between the lack of knowledge and skills related to saving literacy as explained in Table 3 related with finding by (Te'eni-Harari, 2016) that said Children with a significant level of ISM communicated more uplifting perspectives toward saving, just as more certain conduct as to saving and exploration result by Jonubi and Abad (2013) that explained the level of financial literacy had a significant and positive impact on individual saving. Another study by (Muslimin et al., 2020) gave the same conclusion that there's a positive and critical impact of the factors of financial proficiency, peer bunches, and parent's sosioeconomic status towards students' utilization conduct.

The impediment from this exploration that ought to be dissected in future examination is profound different financial and segment factors, for example, age, sexual orientation, pay, conjugal status and instructive achievement that impact the monetary education level. Likewise the utilizing of factual investigation to investigate an interrelationship between monetary information, financial disposition and financial conduct.

\section{CONCLUSION}

This research found that there is the lack of economic literacy among primary school student in three different aspect including knowledge, attitude, and skill. On knowledge aspect, indicated that the lack of their literacy caused by the learning process in school is not really focus on improving student literacy as economy just being a part of social studies subject matter. Student attitude also still not fully wise as expected. Student skills related to economic literacy also still not fully shown that they have a good impression as founded in several activities observed. There is an indication that student knowledge related with their attitude and skill in term of their economic literacy.

\section{REFERENCES}

Akhan, N. E. (2015). Economic Literacy Levels of Social Studies Teacher Candidates. World Journal of Education. https://doi.org/10.5430/wje.v5n1p25

Amagir, A., Groot, W., Maassen van den Brink, H., \& Wilschut, A. (2018). A review of financial-literacy education programs for children and adolescents. In Citizenship, Social and Economics Education. https://doi.org/10.1177/2047173417719555

Amidjono, D. S., Brock, J., \& Junaidi, E. (2016). Financial literacy in Indonesia. In International Handbook of Financial Literacy. https://doi.org/10.1007/978-981-10-0360-8_18

Bosshardt, W. B., \& Walstad, W. (2019). The undergraduate economics coursework of elementary and secondary school teachers. Journal of Economic Education. https://doi.org/10.1080/00220485.2019.1654952

Bosshardt, W., \& Walstad, W. B. (2014). National standards for financial literacy: Rationale and content. Journal of Economic Education. https://doi.org/10.1080/00220485.2014.859963

Burkhardt, G., Monsour, M., Valdez, G., Gunn, C., Dawson, M., Lemke, C., Coughlin, E., Thadani, V., \& Martin, C. (2003). enGauge 21st Century Skills: Literacy in the digital age. In North Central Regional 
Educational Laboratory and the Metiri Group.

Ciemleja, G. (2016). Financial literacy of latvian citizens: Findings and conclusions. WMSCI 2016 - 20th World Multi-Conference on Systemics, Cybernetics and Informatics, Proceedings.

Garg, N., \& Singh, S. (2018). Financial literacy among youth. In International Journal of Social Economics. https://doi.org/10.1108/IJSE-11-2016-0303

Happ, R., Förster, M., Zlatkin-Troitschanskaia, O., \& Carstensen, V. (2016). Assessing the previous economic knowledge of beginning students in Germany: Implications for teaching economics in basic courses. Citizenship, Social and Economics Education. https://doi.org/10.1177/2047173416646597

Henning, M. B., \& Lucey, T. A. (2017). Elementary Preservice Teachers' and Teacher Educators' Perceptions of Financial Literacy Education. The Social Studies. https://doi.org/10.1080/00377996.2017.1343792

Jayaraman, J. D., \& Jambunathan, S. (2018). Financial literacy among high school students: Evidence from India. Citizenship, Social and Economics Education. https://doi.org/10.1177/2047173418809712

KOMŞU, U., Samırkaş KOMŞU, M., \& BOZ, H. (2018). A Study On the Attitudes of Business Owners Towards Learning and Their Economic Literacy: Case of Mersin. Bartın Üniversitesi Eğitim Fakültesi Dergisi. https://doi.org/10.14686/buefad.404472

Lusardi, A., \& de Bassa Scheresberg, C. (2015). Financial Literacy and High-Cost Borrowing in the United States. SSRN Electronic Journal. https://doi.org/10.2139/ssrn.2585243

Muslimin, F., Hanum, F., \& Septia, A. Q. (2020). The Effect of Economic Literacy, Peer Groups, and Parents Socioeconomic Status Towards Students' Consumption Behavior. Dinamika Pendidikan. https://doi.org/10.15294/dp.v15i1.23993

Nurjanah, S., Ilma, R. Z., \& Suparno, S. (2018). Effect of Economic Literacy and Conformity on Student Consumptive Behaviour. Dinamika Pendidikan. https://doi.org/10.15294/dp.v13i2.18330

Opletalová, A. (2015). Financial Education and Financial Literacy in the Czech Education System. Procedia - Social and Behavioral Sciences. https://doi.org/10.1016/j.sbspro.2015.01.229

Salemi, M. K. (2005). Teaching Economic Literacy: Why, What and How. International Review of Economics Education. https://doi.org/10.1016/S1477-3880(15)30132-8

Sari, R. C., Fatimah, P. L. R., \& Suyanto. (2017). Bringing Voluntary Financial Education in Emerging Economy: Role of Financial Socialization During Elementary Years. Asia-Pacific Education Researcher. https://doi.org/10.1007/s40299-017-0339-0

Sutter, M., Zoller, C., \& Glätzle-Rützler, D. (2019). Economic behavior of children and adolescents - A first survey of experimental economics results. European Economic Review. https://doi.org/10.1016/j.euroecorev.2018.09.004

Te'eni-Harari, T. (2016). Financial literacy among children: the role of involvement in saving money. Young Consumers. https://doi.org/10.1108/YC-01-2016-00579

Thibaut, P., \& Curwood, J. S. (2018). Multiliteracies in Practice: Integrating Multimodal Production Across the Curriculum. Theory into Practice. https://doi.org/10.1080/00405841.2017.1392202

Whitlock, A. M. M. (2018). Elementary school entrepreneurs. Interdisciplinary Journal of Problem-Based Learning. https://doi.org/10.7771/1541-5015.1780

Yayar, R., \& Karaca, Ö. (2017). Economic literacy levels of public officers in Turkey. Pakistan Journal of Commerce and Social Sciences (PJCSS). 